\title{
OCCURRENCE OF BLOCKAGE IN CUT STEMS OF Clematis L.
}

\author{
Agata Jędrzejuk, Julia Rochala, Julita Rabiza-Świder
}

\author{
Department of Ornamental Plants, Faculty of Horticulture and Landscape Architecture \\ Warsaw University of Life Sciences - SGGW \\ Nowoursynowska 166, 02-787 Warsaw, Poland \\ e-mail: agata_jedrzejuk@sggw.pl
}

Received: 11.07.2012

\begin{abstract}
During vase life of cut flowers obstructions in stem xylem vessels develop. Such obstructions may restrict water uptake in stems and its transport towards flowers, thus lowering their ornamental value and longevity. Clematis is a very attractive plant which can be used as a cut flower in floral compositions. However, nothing is known about the histochemical or cytological nature of xylem blockages occurring in cut stems of this plant. Observations carried out on Clematis cv. 'Solidarność' proved that tyloses appeared as a principal source of xylem blockage in cut stems. The preservative composed of $200 \mathrm{mg}$ $\times \mathrm{dm}^{-3} 8$-HQC (8-hydroxyquinolin citrate) and $2 \%$ sucrose arrested development of xylem blockage, while the vessels in stems kept in water were filled with tyloses or an amorphic substance. PAS reaction proved that polysaccharides were present in the xylem occlusions, whereas no homogalacturonans were immunolocalized in tyloses using JIM 5 and JIM 7 antibodies. The present study provides new information on the origin of xylem occlusions in clematis and their development in two different vase solutions. Such information can be useful to develop proper postharvest treatments aiming to improve keeping qualities of this new cut flower.
\end{abstract}

Key words: postharvest quality, tyloses, xylem anatomy, Clematis L.

\section{INTRODUCTION}

The dynamic floriculture industry is constantly looking for new products and technologies which may interest potential customers and create new employment opportunities for European growers and breeders of ornamental plants. Clematis is used in Europe mostly as a climber plant, but because of its beautiful flowers this genus might also be successfully used in floral compositions. Several cultivars have already proved to be a potential source of new cut ornamental material (Skutnik and Rabiza-Świder, 2005). The postharvest life of clematis ranges between 2 to 14 days and depends on the cultivar. A preservative effectively extending the vase life of clematis is a solution composed of $200 \mathrm{mg} \times \mathrm{dm}^{-3} 8$-HQC (8-hydroxyquinoline citrate) plus $2 \%$ sucrose (Skutnik and R a biza-Świder, 2005). Because it is a new species for floriculture, more advanced studies and research on senescence of this plant are needed which would allow methods of its postharvest treatments and suitable preservatives to be developed. The vase life of cut flowers is often shortened due to blockage of water uptake in xylem vessels occurring in stems due to microbial growth, formation of tyloses, the presence of air emboli in the vascular system, and deposition of amorphic substances (van Doorn, 1997; Twu$\mathrm{m}$ as $\mathrm{i}$ et al. 2005). The appearance of occlusions in xylem conduits is a common response to environmental stresses, infection by microorganisms, or mechanical injury. This kind of blockage effectively restricts water uptake by xylem vessels and prevents air embolism (Zimmermann, 1983; S un et al. 2008). The nature of such blocking material was investigated cytologically in xylem vessels in some woody species like Prunus pensylvanica, Ulmus americana, Sorbus americana, revealing the presence of pectic elements, callose or lignin-like molecules ( $\mathrm{R}$ i o u x et al. 1998; Espino and Schenk, 2011).

Our earlier studies revealed the occurrence of tyloses in cut clematis stems ( $\mathrm{J}$ ę drzejuk et al. 2012). This trial was conducted to provide immunohistochemical information on chemical nature of vessel occlusions in cut clematis stems kept in water and in a preservative solution. 


\section{MATERIALS AND METHODS}

\section{Plant material}

Flowering stems of Clematis 'Solidarność' which were used as plant material for histochemical, immunohistochemical and cytological studies were kindly provided by Szczepan Marczyński and Władysław Piotrowski from the 'Clematis' plant nursery in Duchnice near Warsaw. The choice of this cultivar was based on the observations of vase life made by $\mathrm{Skutnik}$ and $\mathrm{R}$ abiza-S wider $(2005,2006)$. Flowers were harvested at the same stage of development, i.e. open flowers with no visible mechanical defects or symptoms of disease or insect pests. The cut shoots were placed in vases with either distilled water or a preservative solution containing $2 \%$ sucrose and $8 \mathrm{HQC}-8$-hydroxyquinoline citrate $\left(200 \mathrm{mg} \times \mathrm{dm}^{-3}\right)$. The shoots were kept under controlled conditions: temperature $20^{\circ} \mathrm{C}$, relative air humidity $60 \%$, light intensity $35 \mu \mathrm{mol} \times \mathrm{m}^{-2} \times \mathrm{s}^{-1}$, and 12 hours light and 12 hours darkness. After 7 or 12 days of vase life, the lower stem parts were cut off to be compared to these taken from freshly harvested flowers. 10 shoots were taken for microscopic observations from each treatment and each harvest date (after 7 or 12 days).

\section{Cytology, histochemistry} and immunolocalization

For microscopic observation, the stem basal parts about $5 \mathrm{~mm}$ long were sampled on three dates: immediately after cutting (control, date 0 ), after 7 days of postharvest life when flowers started wilting in water (date I), and after 12 days, when wilting occurred in flowers kept in the preservative (date II). On date I and II the stem fragments were collected from both treatments (distilled water, preservative), from 4-5 stems in each treatment.

The samples were fixed in paraformaldehyde fixative (4\% paraformaldehyde (Sigma), 0.05M phosphate buffered saline (PBS) (pH 7.0), 0.4\% DMSO (Sigma), DEPC - diethylpyrocarbonate - treated water (Sigma) under $0.6 \mathrm{~atm}$ for $12 \mathrm{~h}$. Next, the samples were washed twice for $30 \mathrm{~min}$ in phosphate buffer saline (PBS), dehydrated in increasing concentrations of ethanol series $(30 \%, 50 \%, 70 \%, 80 \%, 95 \%, 100 \%)$, each series for $1 \mathrm{~h}$, and twice in Histoclear (Histochoice clearing agent, Sigma) each time for $30 \mathrm{~min}$. The last step was adding Paraplast pellets (Sigma) to the last series of Histoclear in paraffin oven, twice a day for 6-7 days, in temperature $56-58^{\circ} \mathrm{C}$. Finally, samples were embedded in clear Paraplast (Sigma). Semi-thin sections $(10 \mu \mathrm{m})$ were sectioned on rotary microtome (Reichert Jung). All preparations were put on the RNase, DNase free objective slides (Thermo Scientific MenzelGläser, Superfrost ${ }^{\circledR}$ Plus) and dried in $42^{\circ} \mathrm{C}$ for $2-4$ days.

For conventional ultrastructural observations samples were treated for $24 \mathrm{~h}$ with $5 \%$ glutaraldehyde and $4 \%$ formaldehyde in $0.1 \mathrm{M}$ cacodylate buffer, $\mathrm{pH}$ $7.2-7.3$, at room temperature under a pressure of $0.8 \mathrm{~atm}$.
Next stems were contrasted in $1 \%$ solution of osmium tetroxide $(\mathrm{OsO} 4)$ in $0.1 \mathrm{M}$ buffer cacodylate for $2 \mathrm{~h}$ at room temperature. The next step was dehydration of the samples in the increasing concentrations of ethanol from 10 to $100 \%$ and dehydrated in acetone. Then the Clematis stems were embedded in Epon (Fluka) at $60^{\circ} \mathrm{C}$ for $24 \mathrm{~h}$. The last stage was staining of semi-thin sections of 0.2 microns with $3 \%$ uranyl acetate and citrate by the method of Reynolds (1963) and observed under transmission electron microscope (JEOL JEM100C).

For some cell components, sections were incubated with monoclonal primary antibodies JIM 5, JIM 7 (detection of homogalacturonans) synthesized by Dr J. P. Knox, Centre of Plant Sciences, University of Leeds, Leeds, UK. Primary antibodies (diluted 1:20 in phosphate-buffered saline (PBS)) were applied for $2 \mathrm{~h}$ at $37^{\circ} \mathrm{C}$. Then the anti-rat antibody labeled with alkaline phosphatase (SIGMA) was applied for $2 \mathrm{~h}$ in $37^{\circ} \mathrm{C}$ and next slides were incubated with NBT/BCIP (nitro-blue tetrazolium chloride and 5-bromo-4-chloro-3'-indolyphosphate p-toluidine salt) (Sigma) diluted in $100 \mathrm{mM}$ Tris, $100 \mathrm{mM} \mathrm{NaCl}, 50 \mathrm{mM} \mathrm{MgCl}_{2}$ for $2 \mathrm{~h}$ in darkness. Histochemical and immunohistochemical results were visualized under bright field microscope OLYMPUS BX41.

\section{RESULTS}

\section{Cytological identification of xylem occlusions}

In stems examined immediately after harvest (control) the xylem vessels were free of any occlusions (data not presented). Stems kept in distilled water, on both sampling dates showed presence of tyloses. Tyloses filled mostly the whole lumen of the vessels (Fig. 1). In this treatment the nuclei present in tyloses showed advanced chromatin condensation. Also several autocatalytic vacuoles were present. Stems kept in the preservative solution for 7 days (date I) contained only several tyloses which did not fill the whole lumen of xylem vessel (data not presented).

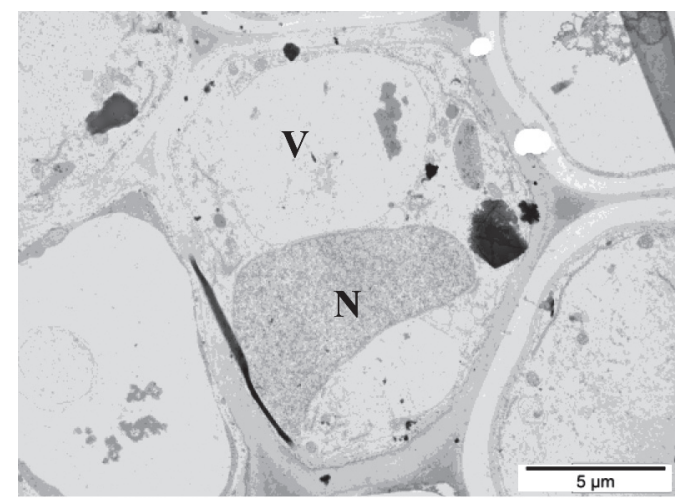

Fig. 1. Ultrastructural identification of xylem occlusions in steams of Clematis 'Solidarność'. Stems kept in distilled water for 12 days, $\mathrm{N}$ - degrading nuclei, $\mathrm{V}$ - vacuole. 


\section{Histological and immunohistological identification of polysaccharides and homogalacturonan epitopes in xylem occlusions in Clematis 'Solidarność'}

The presence of polysaccharide complexes in the stem of Clematis was shown by the periodic acid-Schiff (PAS) method (P e a r s e, 1968). In control stems (date 0), the xylem vessels were free of any blockages. Intense concentration of polysaccharides was evident in the proto and metaxylem cell walls. The red color of the PAS reaction was also visible in pith rays, but the intensity of the color reaction indicated a lower accumulation of polysacharides in the pith cells. Polysaccharides were not observed in the phloem or cambium cells. The brown color of the epidermis was a natural color of the tissue and did not come from the reaction (Fig. 2A).

Stems that were kept in distilled water for 7 days (date I) contained polysaccharide blockages. The intensity of the color ranged between light red in a half of blocked vessels to intense red in completely blocked vessels (Fig. 2B). After 12 days (date II), strongly red stained vessels were also present in protoxylem (data not presented).

In stems kept in the standard preservative solution, completely blocked vessels were not found after 7 days of vase life (Fig. 2C). On date II (after 12 days), only light red color was visible in the blocked and half blocked vessels of these stems (Fig. 2D). In this treatment, only metaxylem showed a weak color coming from the reaction.

In the present study, histological immunolocalization with JIM 5 antibody gave a positive color reaction in phloem, cambium, pith, and particular cells of primary rays. In control stems, the xylem vessels were free of any occlusions (Fig. 3A). No homogalacturonans were present on any date in xylem occlusions in stems placed either in distilled water (Fig. 3B) or in $8 \mathrm{HQC}$ with $2 \%$ sucrose. Jim 7 antibody gave a much weaker signal than Jim 5 antibody (Fig. 3C-D).

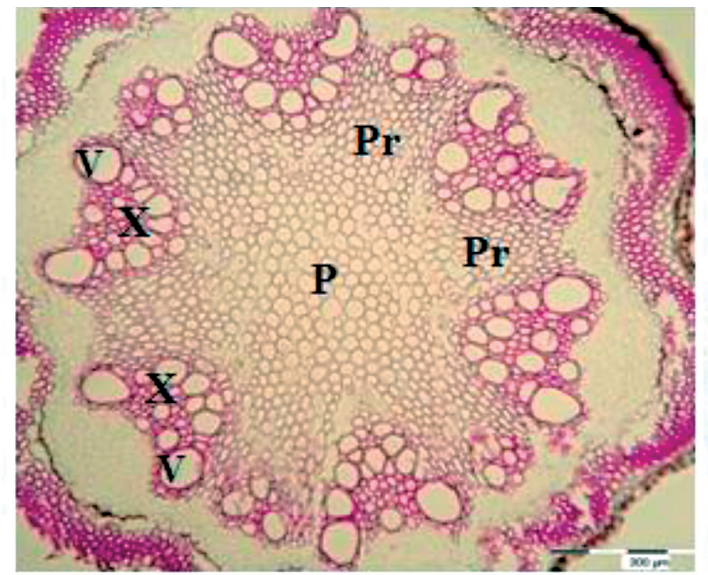

$2 \mathbf{A}$

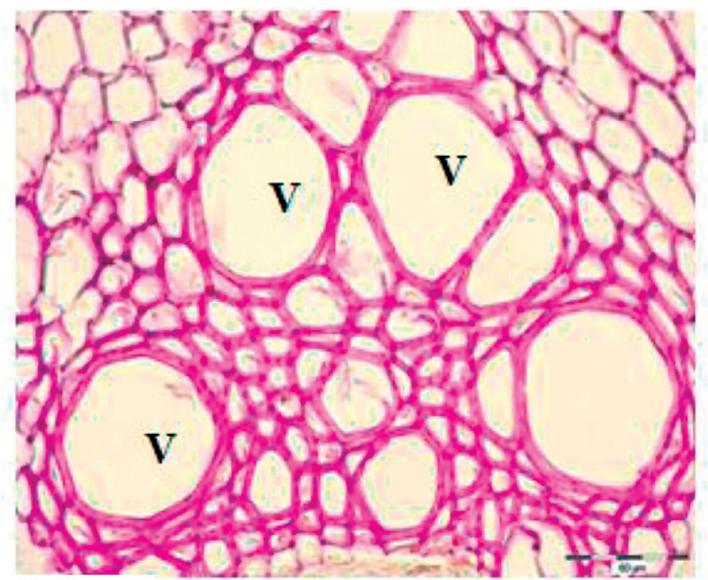

2C



2B

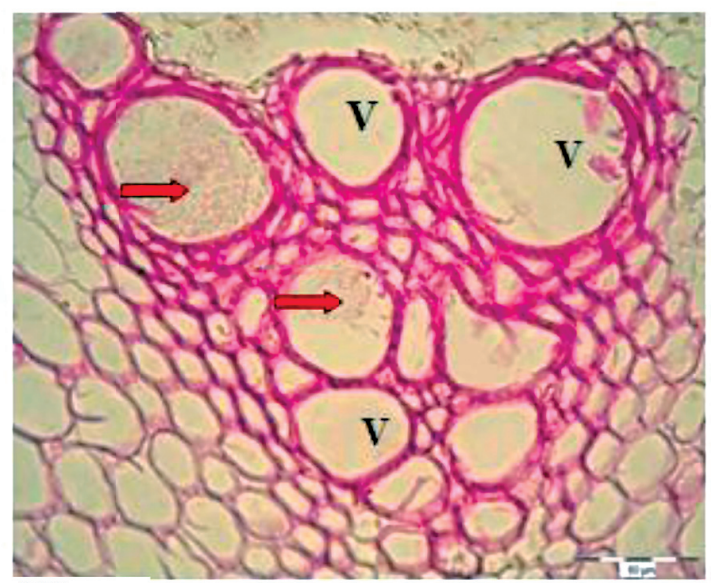

2D

Fig. 2. Histological identification of polysaccharide components in xylem occlusions in steams of Clematis 'Solidarność' by using PAS reaction. A. stem on day $0, \mathrm{P}$ - pith, $\mathrm{Pr}$ - pith radius, $\mathrm{X}$ - xylem, V - vessel. B. stems kept in distilled water for 7 days, $\mathrm{V}$ - vessel, $\longrightarrow$ - blockage in vessel. C. stems kept in preservative for 7 days, V - vessel. D. stems kept in preservative for 12 days, V - vessel, $\longrightarrow$ - blockage in vessel. 


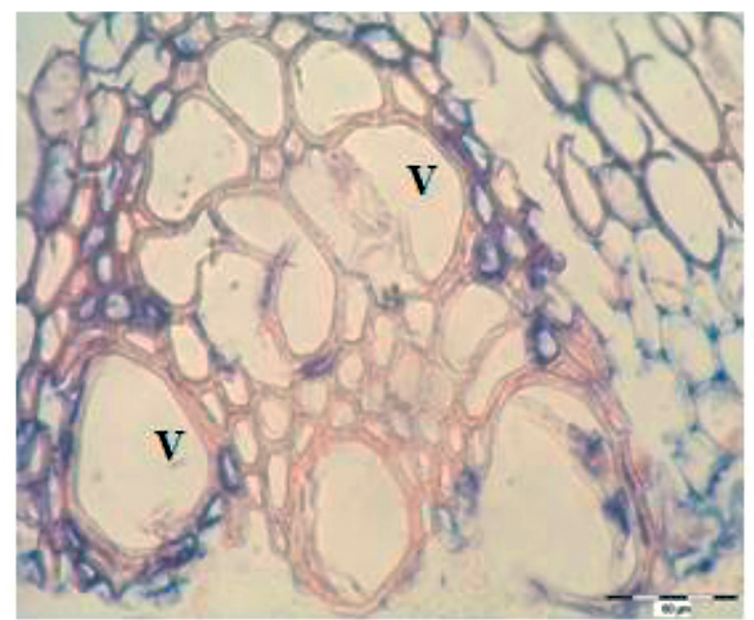

3A

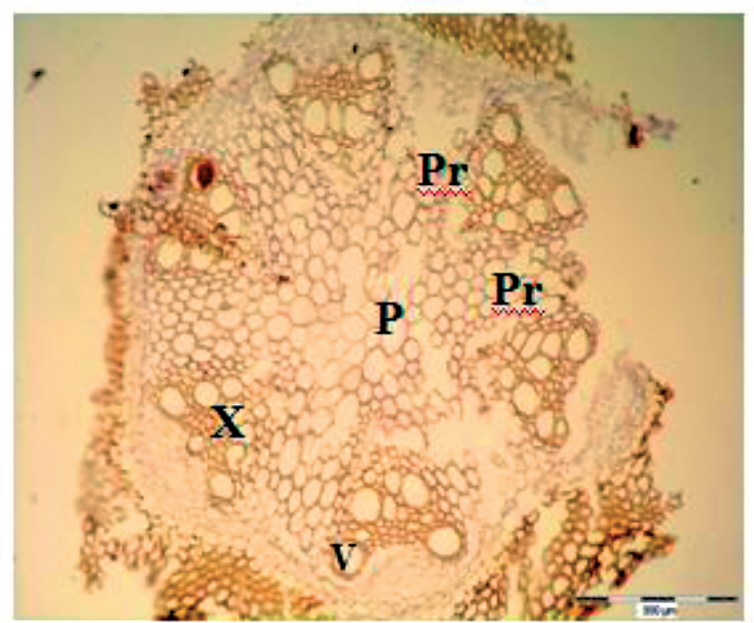

3C

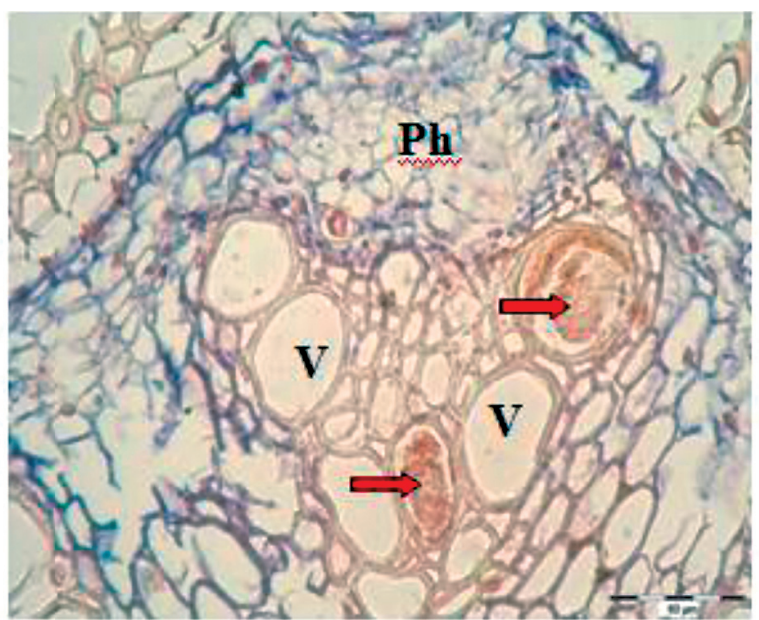

3B

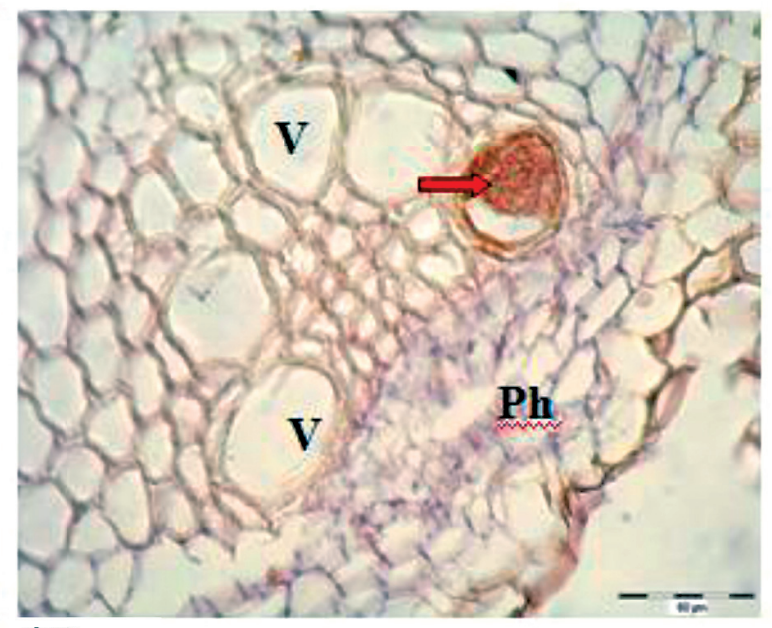

3D

Fig. 3. Immunohistological identification of homogalacturonan epitopes in xylem occlusions in steams of Clematis 'Solidarność' with JIM 5 (A, B) and JIM 7antibodies (C, D) A. stem on day 0, V - vessel. B. stems kept in distilled water for 7 days, Ph phloem, V - vessel, $\longrightarrow$ - blockage in vessel. C. control stems, P - pith, Pr - pith radius, X - xylem, V - vessel. D. stems kept in distilled water for 12 days, $\mathrm{Ph}$ - phloem, $\mathrm{V}$ - vessel, $\longrightarrow$ - blockage in vessel.

\section{DISCUSSION}

According to S y t s e m a - Ka l k m a n (1990), tyloses were found in the xylem vessels of lilac stems where water uptake was blocked or slowed-down. In the present study, in both treatments young tyloses usually had a globular shape which elongated during tylose development. This event may be a result of outgrowths of parenchyma cells that bulge through the circular bordered pit cavities of vessel members $(\mathrm{C} 1 \mathrm{e}$ ri v e t et al. 2000). Thyloses are generally considered as a primary defense mechanism during vascular attacks contributing to stopping the pathogen transportation within xylem vessels ( $\mathrm{O}$ u e $11 \mathrm{e} \mathrm{t} \mathrm{t} \mathrm{e} \mathrm{and} \mathrm{R} \mathrm{i} \mathrm{o} \mathrm{u} \mathrm{x,}$ 1992; V a n dermolen et al. 1987). Earlier studies revealed the process of tylose formation in Clematis stems (J ę d r ze ju k et al. 2012). According to S u n (2008), lignin, proteins and polysaccharides seem to be the main components of xylem occlusions. The large accumulation of lignin and polysaccharides in the blocked vessels and a characteristic oval shape of the occlusions may confirm the presence of tyloses in the xylem of Clematis. A conclusion of our observations was that the tyloses were the principal source of xylem blockage in cut Clematis stems. The way to reduce their development was to keep stems in the preservative composed of 8-HQC and $2 \%$ sucrose.

The strong red color of the xylem occlusions occurring after PAS reaction in Clematis stems kept in distilled water confirmed a high concentration of polysaccharides present in the occlusions. The use of the preservative reduced the number of tyloses which formed in xylem vessels in comparison with stems kept in distilled water, but did not prevent this process completely. Tyloses that occurred in stems kept in the 
standard preservative solution never occluded the whole vessel lumen as it happened in stems kept in water. V a n D o or $n$ and others (1991) confirmed that the use of 8-HQC counteracts the formation of tyloses in many species of ornamental plants, particularly in lilac and rose.

JIM 5 and JIM 7 antibodies recognize homogalacturonan epitopes (C 1 a u s e $\mathrm{n}$ et al. 2003). Histoimmunochemistry did not localize any homogalacturonans in tyloses. According to the literature ( $\mathrm{R}$ i o u x et al. 1998; C l e rivet et al. 2000), a strong concentration of pectins occurs in amorphic substances in xylem vessels, but their presence in tyloses is rather rare. Our research showed that pectins were not histochemically detected - neither in the tyloses nor in amorphous extracellular material occluding xylem vessels. However, in some plants differentiation of tyloses may be correlated with the accumulation of pectins in parenchymatic cells of the pith (C le rive t et al. 2000; $\mathrm{R}$ a j p u t et al. 2009). In Clematis stems, the accumulation of pectin epitopes in pith rays was quite evident, but they were not observed in the tyloses. According to several data (C zaninski, 1972; Cate s s on et al. 1979; C a te s s o n, 1983), pectins are hydrolyzed in the pith membranes by the time the xylem cells die, whereas highly methylated pectins remain. The recent data presented by S u n et al. (2008), P lav c ov a et al. (2011), and Gortan et al. (2011) seem to invalidate the above hypothesis by proving that pectins can be deposited on pit membranes between xylem conduits after serious physiological stress such as wounding or pathogen infection. In cut Clematis stems that are under physiological stress (wounding, water stress), pectins were localized by JIM 5 and JIM 7 antibodies in the pith area, but no evidence was found for their presence in xylem. These results may confirm the hypothesis which claims that pectin epitopes are not present in xylem.

The results of these trials confirmed efficiency of the solution composed of 8-HQC and sucrose in limiting blockages in cut Clematis stems. Unobstructed water uptake and transport to flowers is prerequisite for proper flower bud opening and good vase life ( $\mathrm{v}$ a $\mathrm{n}$ D o o r n , 1991). Studies on the effect of different biocides on blockade forming in cut Clematis stems will be continued in order to find an optimal preservative for this species.

\section{CONCLUSIONS}

1. Tyloses were a principal source of xylem blockage in cut Clematis stems.

2. Polysaccharides were present in xylem occlusions.

3. No homogalacturonans were immunolocalized in tyloses using JIM 5 and JIM 7 antibodies.
4. Placing stems in the standard preservative (8-HQC $+2 \% \mathrm{~S}$ ) reduced the number of tyloses but did not completely prevent their formation.

\section{Acknowledgements}

The experiments were carried out within the framework of the project N N310 089336 of the Ministry of Science and Higher Education. The authors are grateful to Sz. Marczyński and W. Piotrowski of the Clematis nursery for providing plant material for the experiment.

\section{REFERENCES}

Catesson A.M., Czaninski Y., Moreau M., Peresse M. 1979. Conséquences d'une infection vasculaire sur la maturation des vaisseaux (Consequences of the infection on the maturation of vascular vessels). Rev. Mycol. 43: 239-243.

Catess on A.M. 1983. A cytochemical investigation of the lateral walls of Dianthus vessels. Differentiation and pit-membrane formation. IAWA Bull. 4: 89-101.

Clausen M.H., Willats W.G.T., Knox J.P. 2003. Synthetic methyl hexagalacturonate hapten inhibitors of antihomogalacturonan monoclonal antibodies LM7, JIM5 and JIM7. Carbohydrate Research, 338: 17971800.

Clerivet A., Deon V., Alami I., Lopez F., Geiger J.P., Nicole M. 2000. Tyloses and gels associated with cellulose accumulation in vessels are responses of plane tree seedlings (Platanus $x$ acerifolia) to the vascular fungus Ceratocystis fimbriata $\mathrm{f}$. sp platani. Trees, 15: 25- 31.

Czaninski Y. 1972. Observations ultrastructurales sur l'hydrolyse des parois primaries des vaisseaux chez le Robinia pseudo-acacia L. et l'Acer pseudoplatanus L. C R Acad. Sci. (Paris) 275: 361-363.

Espino S., Schenk H.J. 2011. Mind the bubbles: achieving stable measurements of maximum hydraulic conductivity through woody plant samples. J. Exp. Bot. 63: 1119-1132.

Gortan E., Nardini A., Salleo S., Jansen S. 2011. Pit membrane chemistry influences the magnitude of ion-mediated enhancement of xylem hydraulic conductance in four Lauraceae species. Tree Physiol. 31: 48-58.

Jędrzejuk A., Rochala J., Zakrzewski J., Rabiza-Świder J. 2012. Identification of xylem occlusions occurring in cut clematis (Clematis L.) stems during their vase life. The Scientific World J. Article ID: 749281, 12 pages, doi:10.1100/2012/749281

Ouellette G.B., Rioux D. 1992. Anatomical and physiological aspects of resistance to Dutch elm disease. [In:] A. Blanchette, A. Biggs (eds) Defense mechanisms of woody plants against fungi. Springer, Berlin, Heidelberg, New York: 257-307. 
Pearse A.G. 1968. Histochemistry (theoretical and applied). London, UK: J.\& A. Churchill Ltd: 378.

Plavcová L., Hacke U.G., Sperry J.2011. Linking irradiance-induced changes in pit membrane ultrastructure with xylem vulnerability to cavitation. Plant Cell Environ. 34: 501-513.

Rajput K.S., Sanghvi G.V., Koyani R.D., Rao K.S. 2009. Anatomical changes in the stems of Azadirachta indica (Meliaceae) infected by pathogenic fungi. IAWA J. 30: 27-36.

Reynolds E.S. 1963. The use of lead citrate at high $\mathrm{pH}$ as an electron-opaque stain for electron microscopy, J. Cell Biol. 17: 208.

Rioux D., Nicole M., Simard M., Ouellette G.B. 1998. Immunocytochemical evidence that secretion of pectin occurs during gel (gum) and tylosis formation in trees. Phytopathology, 88: 494-505.

Skutnik E., Rabiza-Świder J. 2005. Przydatność kwiatów ciętych wybranych odmian powojnika (Clematis L.) do wykorzystania we florystyce. / Testing some the usefulness of cultivars of clematis (Clematis L.) as cut flowers. Zesz. Probl. Post. Nauk Rol. 504: 507-513. (in Polish)

Skutnik E., Rabiza-Świder J. 2006. Wpływ chłodzenia na pozbiorcza trwałość wybranych odmian powojnika (Clematis L.) / The influence of cooling on postharvest longevity of chosen cultivars of clematis (Clematis L.). Zesz. Probl. Post. Nauk Rol. 510: 587592. (in Polish)

Sun Q, Thomas L, Rost TL, Matthews MA. 2008. Wound-induced vascular occlusion in Vitis vinifera (Vitaceae): Tyloses in summer and gels in winter. Am. J. of Bot. 95: 1498-1505.

Sytsema-Kalkman E.C. 1990. Na-oogst onderzoek sering (3). Thyllen waarschijnlijk oorzaak vaatverstopping. Vakblad voor de Bloemisterij, 45 (48): 47.

Twumasi P., van Ieperen W., Woltering E.J., Emons A.M.C, Schel J.H.N., Snel I.H.F., van Meeteren U., van Marwijk D.2005. Effects of water stress during growth on xylem anatomy, xylem functioning and vase life in three Zinnia elegans cultivars. In: Marissen N., van Meeteren U., van Doorn W. (eds.) Proc. VIII ${ }^{\text {th }}$ IS Postharvest Phys. Ornamentals. Acta Hort. 669: 303-311.
Vandermolen G.E., Beckman C.H., Rohehorst E. 1987. The ultrastructure of tylose formation in resistant banana following inoculation with Fusarium oxysporum f. sp. Cubense. Physiol. Plant Pathol. 31: 185-200.

van Doorn W.G., Harkema H., Otma E. 1991. Is vascular blockage in stems of cut lilac flowers mediated by ethylene? Acta Hort. 298: 177-181.

va n D o or n W. G. 1997. Water relations of cut flowers. Hortic. Rev. 18: 1-85.

Zimmermann M. 1983. Xylem Structure and the Ascent of Sap. Springer-Verlag. Berlin, Heidelberg, New York, Tokyo: 96-104.

\section{Występowanie blokad w ciętych pędach powojnika Clematis $\mathrm{L}$.}

\section{Streszczenie}

Podczas życia w wazonie kwiatów ciętych mogą pojawić się blokady hamujące swobodny transport wody w pędach. Blokady te skutecznie utrudniają swobodny przepływ wody, powodując tym samym obniżenie wartości kwiatów oraz skracając ich trwałość. Powojnik jest niezwykle atrakcyjną rośliną wykorzystywaną jako pnącze ogrodowe, a od niedawna także w bukietach. Do tej pory nie prowadzono badań nad trwałością posprzętną tej rośliny oraz nad charakterem blokad występujących w pędach powojnika. Obserwacje prowadzone na odmianie 'Solidarność' pokazały, że głównym źródłem blokad pędów u powojnika są wcistki. Pożywka składająca się z $200 \mathrm{mg} \times \mathrm{dm}^{-3}$ $\times 8$-HQC (cytrynian 8 hydroksykinoliny) $\mathrm{z}$ dodatkiem $2 \%$ sacharozy skutecznie zahamowała rozwój blokad w pędach, w przeciwieństwie do wody destylowanej. Reakcja PAS pokazała, że jednym z komponentów wcistek były wielocukry, jednak nie wykryto wśród nich pektyn i homogalakturonianów. Przeprowadzone obserwacje dostarczyły informacji na temat blokad występujących w ciętych pędach powojników, co pozwoli na stworzenie precyzyjnych procedur mających na celu skuteczne przedłużenie trwałości ciętych powojników. 